\title{
EDUCATIONAL COMPETIOTION AS A MODERATING VARIABLE OF THE RELATIONSHIP BETWEEN ELECTRONIC MANAGEMENT AND INTELLIGENT ORGANIZATIONS
}

\section{LA COMPETENCIA EDUCATIVA COMO VARIABLE DE MODERACIÓN DE LA RELACIÓN ENTRE LA GESTIÓN ELECTRÓNICA Y LAS ORGANIZACIONES INTELIGENTES}

\section{COMPETIÇÃO EDUCACIONAL COMO VARIÁVEL DE MODERAÇÃO DA RELAÇÃO ENTRE GERENCIAMENTO ELETRÔNICO E ORGANIZAÇÕES INTELIGENTES}

\begin{abstract}
The research aims to determine the modified role of Educational Competiotion to enhance the impact of electronic management in intelligent organizations. The research started from several questions to know the interactive role of Educational Competiotion in enhancing electronic management and its impact on activating intelligent organizations. The research aimed to reach the essence of theoretical philosophy and the intellectual basis of these variables as one of the important issues in modern administrative thought. And its relationship and its direct and indirect effects were diagnosed through the modified role. The research sample consisted of a number of employees in Asia-Cell Company in the city of Karbala. Their number reached (129), and the questionnaire was used to collect data and a number of statistical methods were used to prove the validity of the hypotheses. The results were identical to the main hypothesis. On this basis, a number of conclusions were drawn, the most important of which was that Educational Competiotion modifies the positive relationship between electronic management and intelligent organizations. There should also be awarenessraising sessions on the importance of Educational Competiotion to take advantage of opportunities and explore new opportunities.
\end{abstract}

Keywords: Electronic Management, Educational Competioti, intelligent organizations.

Resumen: La investigación tiene como objetivo determinar el papel modificado de la competencia educativa para mejorar el impacto de la gestión electrónica en las organizaciones inteligentes. La investigación comenzó a partir de varias preguntas para conocer el papel interactivo de la competencia educativa en la mejora de la gestión electrónica y su impacto en la activación de

\footnotetext{
${ }^{1}$ University of Kerbala. Karbala, Iraq
} 
organizaciones inteligentes. La investigación tuvo como objetivo alcanzar la esencia de la filosofía teórica y la base intelectual de estas variables como uno de los temas importantes en el pensamiento administrativo moderno. Y su relación y sus efectos directos e indirectos fueron diagnosticados a través del rol modificado. La muestra de investigación consistió en una serie de empleados en AsiaCell Company en la ciudad de Karbala. Su número alcanzó (129), y el cuestionario se utilizó para recopilar datos y se utilizaron varios métodos estadísticos para probar la validez de las hipótesis. Los resultados fueron idénticos a la hipótesis principal. Sobre esta base, se sacaron una serie de conclusiones, la más importante de las cuales fue que la competencia educativa modifica la relación positiva entre la gestión electrónica y las organizaciones inteligentes. También debería haber sesiones de sensibilización sobre la importancia de la competencia educativa para aprovechar las oportunidades y explorar nuevas oportunidades.

Palabras clave: gestión electrónica, competencia educativa, organizaciones inteligentes.

Resumo: A pesquisa tem como objetivo determinar o papel modificado da Competição Educacional para aumentar o impacto do gerenciamento eletrônico em organizações inteligentes. A pesquisa partiu de várias perguntas para conhecer o papel interativo da Competição Educacional no aprimoramento do gerenciamento eletrônico e seu impacto na ativação de organizações inteligentes. A pesquisa objetivou alcançar a essência da filosofia teórica e a base intelectual dessas variáveis como uma das questões importantes do pensamento administrativo moderno. E seu relacionamento e seus efeitos diretos e indiretos foram diagnosticados através do papel modificado. A amostra da pesquisa consistiu em vários funcionários da Asia-Cell Company, na cidade de Karbala. Seu número foi alcançado (129), e o questionário foi usado para coletar dados e vários métodos estatísticos foram usados para comprovar a validade das hipóteses. Os resultados foram idênticos à hipótese principal. Com base nisso, várias conclusões foram tiradas, sendo a mais importante que a Competição Educacional modifica a relação positiva entre gerenciamento eletrônico e organizações inteligentes. Também deve haver sessões de conscientização sobre a importância da Competição Educacional para aproveitar as oportunidades e explorar novas oportunidades.

Palavras-chave: Gerenciamento Eletrônico, Competição Educacional, organizações inteligentes.

\section{INTRODUCTION}

The world today is witnessing rapid development in the information revolution, artificial intelligence and the spread of the Internet. This directly affected administrative and organizational functions, which required the creation of legal and regulatory implications stemming from the characteristics of the electronic revolution. In order to face these challenges, the organization must work hard to achieve continuous success in the environment and Educational Competiotion is one of the most important options used by contemporary organizations to deal seriously with the environment. Educational Competiotion has become an integral part of the strategies of contemporary organizations to maintain their competitiveness. This has led many organizations to reconsider the mechanisms of the work of contemporary organizations and to build and develop their activities to be knowledge-oriented in order to form intelligent organizations. 
The importance of electronic management is represented in its contribution to improving the performance of employees and upgrading the level of service provided. The transformation from traditional to electronic management saves time and effort and reduces administrative costs. Electronic management also reduces administrative distances and management control over the organization's life. Through the review of previous studies, electronic management contributes to increased Educational Competiotion. The ambidexterity of organizations is to exploit available competencies and explore new opportunities. Organizations that seek to be proficient in their activities must have big data to be able to use them to achieve their goals. Educational Competiotion contributes to building intelligent organizations. The transition from traditional organizations to intelligent organizations is one of the issues of the current era. The meeting of electronic management and Educational Competiotion together have the potential to make the organization pioneering and creative and then transform into an intelligent organization. In addition, the importance of research stems from the fact that organizations are always looking for ways and means to achieve ambidexterity, cope with changes in events and intensify competition. Search variables are one way to achieve this feature. There is also a paucity of studies and research on the relationship between electronic management and Educational Competiotion and their impact on building intelligent organizations. No study of these variables has ever been observed.

This research seeks to identify a number of important objectives:

1. Determine the availability of each of the requirements (administrative, technical, human resources) for electronic management.

2. Determine the awareness of employees of the advantages of electronic management and intelligent organizations.

3. Check the dimensions of the search variables and whether they are in the direction of strength or weakness.

4. Explain the direct and indirect impact of electronic management and Educational Competiotion on intelligent organizations.

5. Identify important points to transform into intelligent organizations.

6. Provide an information base for those interested in the current research topic from the managers of other organizations. It is considered as a force that supports their ideas and ambitions to provide the necessary foundation for the development of electronic management and the support of Educational Competiotion. In order to develop their vision, mission, and goals to be able to build intelligent organizations. 
Therefore, technical changes have become imposed on management and organizations. Organizations have to go along with changes in the current era in order to stay away from isolation and exclusion. As electronic management is a new model capable of coping with environmental changes if the organization has the Educational Competiotion in which the organization adopts new forms in dealing with the changing environment. These organizations will be able to excel by having a certain amount of data to help them meet these challenges. This will give sustainability to organizations and provide the basic environment that forms the characteristics of intelligent organizations. The success of any organization in the long term requires that they possess the intelligent characteristics of the entrepreneur. Through this, we ask a number of questions:

1- What is the extent to which the dimensions of (e-management, Educational Competiotion, intelligent organizations) in the application environment?

2- Identify the most important concepts and features that dealt with the variables of research

3- Are there logical relations between search variables?

\section{THEORETICAL SIDE AND THE CONSTRUCTION OF HYPOTHESES}

\section{Electronic Management}

Known as the business system and activities that are implemented electronically across networks. It is the management process based on the unique potential of the Internet and business networks in planning and controlling the organization's core resources and capabilities (Al-Jumaili, 2018). The operation and management of the organization electronically requires training in the implementation of the work electronically and after the selection and appointment, description, analysis, and evaluation of functions and identify the strategic plan and the workflow. Describing the authorities, responsibilities, powers, and questions. All communications and electronic files are carried out, as well as storage and retrieval of information to support decisions, avoid duplication standard of work, prevent duplication and support senior management with documentation, coordination, and follow-up to ensure the safety and security of information (Judy and Abdulrahman, 2011). Electronic management consists of a group of central entities to manage the business in the organization and works through a system of technical procedures and programmed systems and high technology with the cohesion of knowledge bases and digital communication 
systems within the integrated circles of planning, organizing, coordinating and control (Zidane and others, 2018).

The electronic management depends on the development of the information infrastructure within the organization. And agree on the importance of information and reliance on technologies in electronic communication and speed in the achievement of it should be noted that not every organization owns a website is an electronic organization. The right electronic management is to bring this organization back to thinking about how to do business and to use modern technology to modernize and develop all traditional businesses and transform them into e-business (Dahis and others, 2013). Electronic management aims to transform organizations from disciplined hierarchical structures directed by the command and control unit into flexible, simple organizations adapted to internal and external changes. It is like re-engineering business using information technology since old management models and traditional treatments are no longer suitable for e-organization models. It is a new field that emerged as a result of the convergence of information technology and Internet technologies and new business models in the knowledge economy and competition (Hassan, 2013).

Electronic management, in its traditional sense, is no longer able to achieve the objectives of the organizations in the light of technological and cognitive development in information systems. As they are rigid organizations in place and time specific (Hassan and others, 2016). Among the reasons for the transition to electronic management is the increase in complex procedures and processes and the high costs of traditional management, the need to consolidate data at the level of the organization, the tendency to employ the use of technological development and reliance on information in decision-making as well as increased competition among organizations, and the need for mechanisms for excellence within the organization (Jafar, 2014).

Both Badran and Mohsen, (2014), Asadi, (2009) identified the objectives of electronic administration as follows:

1. Reduce the cost of administrative procedures and related transactions.

2. Manage and follow up the various departments easily as one central unit.

3. Reduce the constraints of decision-making by providing data and information to beneficiaries.

4. Increase the efficiency of the work of management in daily transactions.

5. Fulfilling more clients simultaneously without delay in delivery. 
6. Canceling the paper archive system and replacing it with electronic archiving, thus saving costs.

7. Emphasis on the principle of total quality in its modern concept by meeting the needs of the client in the time in which the customer needs to service and as soon as possible.

He pointed out both Al-Oqaby and Al-Rabeay, (2018), Aboudi and Yahya, (2018), Shahab, (2013) to the requirements of electronic management and have been classified at three levels:

Administrative requirements: It is essential for the implementation of electronic management as it contributes to change and development and supports modern administrative methods as well as developing strategies and coordination plans and development of administrative systems, implementation of administrative reform plans, providing specialized competencies and skills and using the consultancy and research to participate in the establishment and development of electronic management. And that e-leadership that deals with information technology and communication skills. Among the requirements, which are the most important point is the existence of legislation and legal texts facilitate the work of electronic management and the spread of electronic security and confidentiality to protect information.

Technical requirements: The set of physical components through which applications can be implemented and linked to the creation of computers, complete data systems, and connected servers within an internal and external Intranet network to increase interconnection between different administrative systems. The prices of these devices must be reasonable and commensurate with the size of the organization.

Human requirements: The human element is one of the most important resources that can be invested to achieve success in any project and it is important in the application of electronic management is discovered and developed to achieve its objectives. Understanding the experts and specialists in the field of knowledge who represent the infrastructure and intellectual capital of the organization. The human requirements are to attract the best-qualified individuals in the fields of information systems and software and to find effective systems to maintain, develop and motivate individuals, and to empower individuals and provide opportunities for them to deal quickly with changes in the technological environment. And the introduction of workers in training programs and within different periods.

Dahwan, (2008), Daini, (2010) pointed to the importance of electronic management as a cornerstone of intelligent business organizations. This importance is attributed to several reasons: 
1. Help improve the organization's performance in providing services and facilitate the business and transactions provided by the organization to its customers.

2. Reduce costs, increase profitability and move the organizational structure from complex to electronic form, which requires a small number of workers without a specific place.

3. The breadth of the markets dealt with by the Organization.

4. Direct production according to the needs and desires of customers by providing feedback service, collecting and analyzing information.

5. Improve employee performance and upgrade the service provided to customers.

\section{Educational Competiotion}

Is the ability to early discover opportunities and invest them before competitors, especially those related to advanced technology and discover new markets before competitors. Regulatory ingenuity represents the ability of decision-makers to do two different things at the same time, especially in relation to investing in current capabilities and studying new opportunities. It thus provides the organization with a range of options for producing important outputs. And the Organization was given greater capacity to deal with tensions and contradictions, adaptation, optimization, and creativity (Lubatkin et al., 2006), (Abboudy and Kharofa, 2018).

Tuan (2016) noted that Educational Competiotion is an inseparable structure that sets out the organization's dual-orientation for exploration and exploitation. At the same time, Educational Competiotion seeks to exploit current competencies and explore new opportunities with equal skill to balance exploitation and exploration. In other words, interested organizations can simultaneously implement exploitation and exploration in order to free the organization from stalemate. He added that the application of Educational Competiotion leads to organizational agility.

Raisch and Birkinshaw (2008) say that it means the organization's ability to be effective in its day-to-day management and adaptable to the changing demand of tomorrow, which means the ability to use both the right and the left equally, Effective use of both exploration and exploitation techniques to be successful.

The complexity and speed of change faced by many organizations make them in a position that requires them to do product development and this requires Educational Competiotion 
Organizations that are capable of achieving a high level of balance between exploitation and exploration are efficient in their management of work requirements and adaptation to environmental changes at the same time. Educational Competiotion is the ability to implement innovation and improve strategies. It also requires adapting activities across multiple organizational levels, including organizational culture and effective strategies of good leadership (Al-Baghdadi, 2015), (Albanna, 2016), (Gibson \& Birkinshaw, 2004).

The importance of Educational Competiotion is to enable organizations to diversify their skills in combining current opportunities and future visions in an uncertain environment and the need to develop the rapid capacity to shift to new opportunities. And coordinate activities with a view to achieving this value, which is the basic condition of success. And highlights the importance of Educational Competiotion in the field of projects and widely in the public and private sectors as a means of delivering new products. It is thus linked to long-term success (Chou et al, 2018), (Hussein and al-Ani, 2018).

Al-Mhasena, (2017) referred to three characteristics of Educational Competiotion:

1. Cognition: The ability to identify opportunities and threats that are based on a balance between central control and decentralization.

2. Snatching: the ability of the organization to seize the new opportunities, which requires consensus among the senior management on the strategic intention and away from the wrong decisions.

3. Restructuring: The ability of the organization to align assets with structures and their composition according to market developments, which gives it a strategic advantage. Ibrahim, (2017) pointed out the need for five conditions for the success of Educational Competiotion:

1. The clarity of the strategic objective, which intellectually highlights the importance of both exploitation and exploration.

2. Knowledge of common identity by clarifying shared visions and values through exploratory and investment units.

3. Ownership of the oldest team of units of strategic exploration and investment clear and balanced and able to deal with situations of change in the external environment.

4. The ability of senior management to resolve tensions.

5. Differentiation between exploitative and exploratory units. Each business unit targets a particular structure, culture, and systems to benefit from organizational assets 


\section{Educational Competiotion Dimensions}

Radhi and Kassem (2018), Sabr and others, (2018), Abboudy and Kharofa, (2018), Tarod, (2016), Popadic et al, (2015) pointed to two dimensions of Educational Competiotion:

1. Exploitation: The organization's ability to carry out continuous improvement processes in order to create long-term value. Products are designed to achieve the satisfaction of existing customers in the markets by improving skills, knowledge, and capabilities, expanding existing distribution channels and maximizing the efficiency of the target. The exploitation is linked to several activities, including efficient production, selection, implementation, and refinement. Exploitation reflects learned learning through local research, refinement of experiences and reuse of existing methods of work. Exploitation is linked to progressive creativity and requires an efficient and efficient process to increase and expand the use of existing assets of the Organization.

2. Exploration: is the process of searching for new opportunities and knowledge. They include a vision based on the search for opportunities to introduce unusual products to enhance the competitiveness of the Organization and the ability to predict the needs of the target market or search for new markets. Exploration is achieved through the development of structural mechanisms that are in line with the competition requirements of the Organization for harmonization and adaptability. (Hussain and AlAni, 2018) noted that the following (Table 1) set by Al-Enezi, 92013) can be used to clarify the difference between exploitation and exploration.

Table 1- difference between exploitation and exploration

\begin{tabular}{llll}
\hline & Statement & Exploitation & Exploration \\
\hline $\mathbf{1}$ & Definition & $\begin{array}{l}\text { Activities designed to meet the needs of } \\
\text { existing customers and existing markets }\end{array}$ & $\begin{array}{l}\text { Activities designed to meet the needs of } \\
\text { new customers and markets }\end{array}$ \\
\hline $\mathbf{2}$ & outputs & $\begin{array}{l}\text { Existing designs, existing markets, New designs, new markets, and new } \\
\text { existing distribution channels }\end{array}$ & $\begin{array}{l}\text { distribution channels } \\
\text { Knowledge } \\
\text { Base }\end{array}$ \\
\hline $\begin{array}{l}\text { Adopts existing knowledge and skills } \\
\text { expansion }\end{array}$ & $\begin{array}{l}\text { Requires new knowledge and acquires } \\
\text { existing knowledge }\end{array}$ \\
\hline
\end{tabular}




\begin{tabular}{llll}
\hline $\mathbf{4}$ & $\begin{array}{l}\text { Produced } \\
\text { from }\end{array}$ & $\begin{array}{l}\text { Refinement, production, efficiency, } \\
\text { implementation }\end{array}$ & $\begin{array}{l}\text { Research, variation, flexibility, scientific } \\
\text { experiment, and risk }\end{array}$ \\
\hline $\mathbf{5}$ & $\begin{array}{l}\text { Performance } \\
\text { applications }\end{array}$ & Short-term & Long-term \\
\hline
\end{tabular}

\section{Intelligent organizations}

Intelligent organizations as a contemporary concept call for change in the way business organizations are managed taking into account the implications of learning, development, training, and development. It is an entrance whose primary goal is to maximize the organization's intelligence and to prepare for acceptance of change, thereby earning the organization the ability to deal positively with change (Radaida, 2016).

Through this, we can find out that intelligent organizations have the ability to use knowledge in all forms to develop competitive strategies and enjoy the speed of movement and lightness to benefit from their knowledge in order to achieve their goals and adapt to environmental challenges. It has the capacity to invest its human resources and develop information technology to suit the current work of the Organization. This gives them a continuation of sustainability (Schwaninger, 2001).

Radhi and Hussein, (2017) referred to a range of characteristics of intelligent organizations

1. Cognition: It is conscious and is directed towards its environment and aware of it and collects and uses organized and unorganized information for each situation in the environment in which it lives.

2. Linking: Intelligent organization links internal and external functions at all levels at the geographical level in a way that leads to achieving the desired results.

3. Accuracy: Use relevant and accurate information to support its decisions in a timely manner and use procedures that are closest to the point of impact and outcome.

4. The exploitation of opportunities: Intelligent organizations face the challenges of the status quo and reserve the right to have more than one attempt to create new opportunities.

5. Empowerment: Intelligent organization has a clear picture of the vision, insight, and memory of the organization of the workers as well as access to information. As well as the power to make a decision. 
6. Prediction: Intelligent organization anticipates and prepares for the future Instead of just having a reaction or correcting procedures, they draw and evaluate their favorites.

Intelligent organizations are those organizations that act effectively in the present and have the ability to deal with the challenges of the future. Which are highly interested in their vitality and success and look beyond the scope of daily work and to long-term sustainable performance and have the ability to make effective strategic decisions and apply best management practices. The Intelligent Organization is represented by the ability of private organizations represented by its director, heads of departments, supervisors, and administrators to be committed to achieving the objectives under all pressures and developing the knowledge of the employees of the organizations through regularity and harmony in the work of the organization. These organizations invest their human talents and information technology through a system of institutional values based on transparency, creativity, and respect (Ghoneim, 2017), (Suweis and Abidin, 2019).

Al-Taei and others, (2013), Cherniss \& Goleman, (2001) noted that intelligent organizations are successful, focus and promote knowledge and individuals and have access to a high level of capacity. These organizations have a number of unique advantages like:

1. Creativity: It is the ability to create modern ideas of this kind and these ideas lead to the realization of new products or services.

2. Take risks: It is intended to take advantage of moderate risks that can be controlled through personal attempts of individuals in risk-taking operations, which can be solved by individuals.

3. Independence: The independent processes that the organization tries to reach, which is the driving force for businessmen in the process of activating their dreams and thus freedom of action to achieve leadership in business.

4. Motivation: Intelligent business organizations are encouraged to provide material and moral incentives to achieve motivation among working individuals.

5. Division of work: Responsibilities are effectively defined in organizations in order to unleash the talent of working individuals by focusing on the appropriate work for them.

6. Future Vision: Intelligent organizations draw a clear future vision through analysis into the external environment and set future plans.

Al-Taei and others, (2013) pointed to a comparison between traditional and intelligent organizations as in the (Table 2). 
Table 2- comparison between traditional and intelligent organizations

Traditional organizations

$1 \quad$ Technical skills training for individuals

2 Reliance on the central organizational structure

3 Attention to the internal environment 西

$4 \quad$ Management deals with the individual as a machine

\section{Intelligent organizations}

The training processes are concerned with the development of working individuals

Dependence on decentralization of
organizational structure
Attention to the internal and external environment

Management treats the individuals as human beings with his rights

\begin{tabular}{llll}
\hline $\mathbf{5}$ & $\begin{array}{l}\text { Non-specialization in jobs and division } \\
\text { accurately }\end{array}$ & Specialization and division of labor accurately \\
\hline $\mathbf{6}$ & $\begin{array}{l}\text { Rewards are awarded on the basis of unfair } \\
\text { contributions to individuals }\end{array}$ & $\begin{array}{l}\text { Rewards are awarded on the basis of equitable } \\
\text { contributions of individuals }\end{array}$ \\
\hline $\mathbf{7}$ & $\begin{array}{l}\text { Performance is low to provide an unsuitable } \\
\text { working environment }\end{array}$ & $\begin{array}{l}\text { Performance is high due to the availability of an } \\
\text { appropriate working environment }\end{array}$ \\
\hline $\mathbf{8}$ & Focus on earning only (economic). & $\begin{array}{l}\text { Focus on social, environmental and economic } \\
\text { attention }\end{array}$ \\
\hline $\mathbf{9}$ & $\begin{array}{l}\text { Planning and control processes } \\
\text { management only }\end{array}$ & $\begin{array}{l}\text { Planning and monitoring processes with the } \\
\text { participation of personnel }\end{array}$ \\
\hline $\mathbf{1 0}$ & $\begin{array}{l}\text { Slow response to rapid technological changes to } \\
\text { the business environment }\end{array}$ & $\begin{array}{l}\text { Rapid response to rapid technological changes to } \\
\text { the business environment }\end{array}$ \\
\hline $\mathbf{1 1}$ & $\begin{array}{l}\text { The life of an individual in a traditional } \\
\text { organization is closed. }\end{array}$ & $\begin{array}{l}\text { The life of an individual in an intelligent } \\
\text { organization is open }\end{array}$ \\
\hline $\mathbf{1 2}$ & $\begin{array}{l}\text { Its short-term outlook } \\
\text { Its long-term outlook }\end{array}$ &
\end{tabular}

Al-Karawi, (2016) says that intelligent organizations are capable of continuous renewal, predicting changes, continuous learning and balancing efficiency, learning, and well-being. The modern concept of intelligent organizations is to try to learn how to use emotional and spiritual intelligence in the organization.

Most studies have emphasized the importance of intelligent and superior organizations in business in particular cases. Some studies have criticized some organizations for disregarding intelligent human resources that interact interactively through knowledge in creating a group of 
intelligent organizations. Skandia has expressed the intelligent organization in an equivalent way, considering the intelligent organization as the sum of intellectual capital and information technology values as explained in the following equation.

Intelligent Organization = Intellectual Capital + IT + Values

The development of an intelligent organization requires mainly the availability of intelligent brains and their ability to invest the rest of the resources and harnessing them in order to expand the area of excellence for their organizations (Firaun and others, 2015).

It highlights the importance of intelligent organizations by investing in their existing minds as well as the information technology available through a value system that relies on transparency and information disclosure and rejects hierarchical structures and functional centers as its basic principles.

\section{Intelligent organizations dimensions}

A number of researchers have agreed on a set of basic dimensions of the intelligent organizations, which are as follows: (Abo-Olba, 2018), (Radaida, 2016), (Firaun, Others, 2015a), (Ghoneim, 2017):

1. Understanding the environment: It is intended to know the environment in which the organization operates through a strategic perspective, systemic thinking, understanding uncertainties. The environment represents all elements and forces surrounding the organization (eg social, economic, political, etc.). The understanding of the environment is meant to control and distribute information between the internal and external environment of the persons concerned in the organization. Intelligent organizations use environmental surveys to avoid surprises at the strategic level and to ensure their long-term health. An intelligent organization can understand the environment by absorbing uncertainties and taking them into account when making decisions, measuring them, managing risks and how to overcome them. In order for the organization to face changes in the external environment, it must start from within to assess its positions and explore the larger picture of the wider environment. And then work internally and cumulatively in the use of thinking and evaluating its position and finding solutions. And the use of systematic thinking in the detection of interconnected environmental relationships and this helps to expand the 
boundaries of the mental models of users and improve their ability to generate evidence and motivation for effective change.

2. Strategic vision: It means defining the path adopted by the organization to achieve its mission in the long and short term under the surrounding environmental conditions and competition. Each organization requires an idea, concept, and organizational principle. Vision means the ability to analyze the environment, chart the future perspectives of the organization, continuously review the strategies with the participation of all the different parties, and apply the principle of strategic management.

3. Continuous Learning: It is the process of constantly acquiring knowledge through experience that results in constant change in behavior. The use of knowledge improves the harmonization of the organization and its environment. An intelligent organization constantly learns to generate greater value in the face of various environmental changes. Through learning, individuals respond to information that poses a real threat and finds the organization's defensive means. One of the reasons for continuous learning is the increasing interest in intellectual capital, the intensification of international competition, intellectual development, which is considered a sustainable competitive advantage, technological developments, the evolution of managerial thought towards learning organizations, and the role of decision-makers in decision-making.

4. Intelligent processes: It is intended to share information while providing information to those who need it in a timely manner, and provide feedback. In order to increase the efficiency and effectiveness of the ability to deal with crises and emergency situations. And the use of modern technologies to accomplish the work. The organization is interested in training employees and developing their skills in the use of information technology.

5. Collective intelligence: It means teamwork through collective intelligence, which contributes greatly to the achievement of work, especially the challenging work, which represents the common activity and high containment towards the organization. It refers to the experimental efforts of the Organization's staff, which contribute above what is assigned to them. One of the implications of this dimension is to provide additional efforts by the group rather than individuals. This makes individuals within the group exert maximum effort in the work that stems from the belief in the goals and values of the organization and the desire to preserve the membership and the collective spirit. 


\section{METHODOLOGY}

\section{Supported metrics in search}

The researcher has relied on many previous studies related to the research variables. Through the review, a number of these measures were taken and amendments were made to them in accordance with the nature of the current research. In the below (Table 3).

Table 3- The following is a brief explanation

\begin{tabular}{|c|c|c|c|c|}
\hline Variables & Variable type & Dimensions & Questions & Sources \\
\hline \multirow[t]{4}{*}{$\begin{array}{l}\text { Electronic } \\
\text { management }\end{array}$} & \multirow[t]{4}{*}{ Independent } & $\begin{array}{l}\text { Administrative } \\
\text { requirements }\end{array}$ & $1-8$ & \multirow{4}{*}{$\begin{array}{l}\text { (Judy and } \\
2011 \text { ) } \\
\text { (Dahes and } \\
\text { 2013) } \\
\text { (Hassan, 2013) }\end{array}$} \\
\hline & & Technical requirements & $9-14$ & \\
\hline & & & & \\
\hline & & Human requirements & $15-21$ & \\
\hline \multirow{2}{*}{$\begin{array}{l}\text { Educational } \\
\text { Competiotion }\end{array}$} & Mediator & Exploitation & $22-26$ & \multirow{2}{*}{$\begin{array}{l}\text { (Hussein and Al-Ani, } \\
2018) \\
\text { (Al-Banna, 2016) } \\
\text { (Al-Mahasna, 2017) }\end{array}$} \\
\hline & & Exploration & $27-31$ & \\
\hline \multirow[t]{5}{*}{$\begin{array}{l}\text { Intelligent } \\
\text { organizations }\end{array}$} & Subordinate & $\begin{array}{l}\text { Understanding the } \\
\text { environment }\end{array}$ & $32-36$ & \multirow{5}{*}{$\begin{array}{l}\text { (Radhi and Hussein, } \\
\text { 2017) } \\
\text { (Ghoneim, 2017) } \\
\text { (Al-Taei et al., 2013) }\end{array}$} \\
\hline & & Strategic vision & $37-41$ & \\
\hline & & Continuous learning & $42-46$ & \\
\hline & & Intelligent Operations & $47-51$ & \\
\hline & & Collective intelligence & $52-56$ & \\
\hline
\end{tabular}

\section{Community and research sample and temporal boundaries}

The branch of Asia Telecom was taken in Karbala governorate as a study case. It is one of the leading companies in the field of cellular communications and covers its network all over Iraq. And that the subject of our study is consistent with this company in the field of electronic management and intelligent organizations. The company is also facing strong competition from other competitors. Which we consider necessary to rely on the company sample study on organizational 
skill to exploit and explore opportunities and achieve more profits. The number of employees in this branch reached (150) employees, most of them are holders of certificates and specialists in the field of communications technology. This company is also distinguished by sending its engineers to training workshops outside of Iraq to increase their skills and this is what made the sample of the current study the closest to our study. A sample consisting of (129) samples were distributed to them.

Based on 2009,219 standard scale in the selection of samples that fit the study population, the sample was an error (3\%). The study period took three months to distribute the questionnaire forms and to conduct interviews with specialists to gather information.

\section{RESULTS}

First: Reliability Analysis

Reliability Analysis means "The level of scale is error-free "The level of internal consistency between different phrases that measure a variable. Reliability means the extent to which a scale produces consistent results if the measurements are repeated a number of times. and the more stable and stable the tool the greater the degree of confidence in it. Moreover, means the possibility of relying on the questionnaire of the list, which is used in the study in terms of the stability of the results obtained if repeated measurement in the same list and circumstances. Confirmation of the persistence of the axes of the questionnaire by calculating Coefficient of Alpha Cronbach, and each phrase in it is consistent with the axis to which the paragraph belongs, and the results of Reliable and Valid as shown in the (Table 4):

Table 4- The results of Alpha Cronbach Coefficients to measure the axes Reliable questionnaire

\begin{tabular}{ccc}
\hline Axis number & Axis name & Coefficient of Alpha Cronbach \\
\hline the first & Electronic management & 0.613 \\
\hline The second & Educational Competiotion & 0.319 \\
\hline the third & intelligent organizations & 0.640 \\
\hline
\end{tabular}

Clearly, the above (Table 4) shows that the reliability coefficients of the axes of values came high-resolution values, ranging alpha Cronbach coefficients for the axes of questionnaire between values (.613- .640), and indicate these values of reliability coefficients The validity of the questionnaire for the application and reliability of its results. 
second: The survey sample members attitudes (Electronic Management - Educational Competiotion - intelligent organizations)

Arithmetic average and the standard deviation calculated to illustrate the attitudes of the study sample on the main and sub-axes of the questionnaire. The response score gives according to the range equation of the value of the arithmetic average for each axis and determines the response score for each phrase or axis is based on the following:

- From 1 to less than 1.80 represent response rate (too weak)

- From 1.80 to less than 2.60 represent response rate (weak)

- From 2.60 to less than 3.40 represent response rate (medium)

- From 3.40 to less than 4.20 represent response rate (high)

- From 4.20 to less than 5 represent response rate (very high)

Table 5- Arithmetic Averages and Standard Deviations of sample members responses around questionnaire axes

\begin{tabular}{|c|c|c|c|c|}
\hline The main axis & Sub-axis & Mean & SD & Response \\
\hline \multirow[t]{4}{*}{$\begin{array}{c}\text { Electronic } \\
\text { management }\end{array}$} & $\begin{array}{l}\text { Administrative } \\
\text { requirements }\end{array}$ & 3.9793 & .57547 & High \\
\hline & Technical requirements & 3.7093 & .56750 & High \\
\hline & Human requirements & 4.5814 & .76748 & Very High \\
\hline & Med & 3.9196 & .45442 & High \\
\hline \multirow{3}{*}{$\begin{array}{l}\text { Educational } \\
\text { Competiotion }\end{array}$} & Exploitation & 3.6163 & .83036 & High \\
\hline & Exploration & 3.3798 & .69814 & medium \\
\hline & Med & 3.4744 & .57829 & High \\
\hline \multirow[t]{6}{*}{$\begin{array}{c}\text { intelligent } \\
\text { organizations }\end{array}$} & $\begin{array}{l}\text { Understanding the } \\
\text { environment }\end{array}$ & 3.4884 & .97721 & High \\
\hline & Strategic vision & 4.2248 & .65373 & Very High \\
\hline & Continuous Learning & 4.0465 & .79903 & High \\
\hline & Intelligent processes & 3.6176 & .77291 & High \\
\hline & Collective intelligence & 4.1111 & .62268 & High \\
\hline & Med & 3.9269 & .48317 & High \\
\hline
\end{tabular}

The (Table 5) shows that the degree of response to the three axes of the questionnaire was very high from in the sample members opinion. The standard deviation values for the three main axes of the questionnaire ranged between (454-578) Which are relatively low values; that means homogeneity of sample responses around organizational dexterity in electronic management and intelligent organizations. 
Moreover, the third axes "intelligent organizations" in the previous table shows the highest in arithmetic average reach (3.927) with high response rate then First Axis "electronic Management" with arithmetic average reach (3.9196) and high response rate. Finally, the second axis "Educational Competiotion" with the arithmetic average is (3.4744) and high response rate also.

\section{Interactions test between study variable}

In this section of the study, the hypotheses of the study will be tested. The main hypothesis test and the sub-hypotheses arising from it will require determining the interactive relationships between the study variables and we use the Moderation Analysis method in this case, which aims to investigate the interaction between the variables, before proceeding to answer the hypotheses of interaction as the main object of this subject, a summary of the interactive relationship and modified analysis will be presented as follows:

\section{Moderation Analysis and Interactions concept}

The interactive model is characterized by three basic variables: the independent variable. In the current study, it is the "electronic management" and the dependent variable, it is represented by "intelligent organizations" and the moderator variable is "Educational Competiotion".

Interaction is defined as the difference in the effect of the moderator variable or the difference in the effect of the modified variable between two steps in Regression that do when the independent variable's effect differs in the dependent variable according to the change of the moderator variable that interacts with the independent variable. Since this method aims to investigate individual differences or situational conditions which influence the strength of the relationship between the independent variable and the dependent variable. That's mean, moderator variable improve the effect of the independent variable with the dependent variable, therefore the moderator variable determines who strongly links the independent variable to the dependent. When analyzing interactions, it has to use The Moderation Analysis which aims to explore the level of interaction between the moderation and independent variables by forming the variable of interaction that enters as a third variable with the independent variable and the moderation variable in The Hierarchical Multiple Regression Analysis, which is adopted as the main statistical technique in this type. 
In another hand, the choice of the modified variable must be based on a scientific basis that is consistent with the method of selecting the independent variable. Therefore, the logical acceptance of the moderator variable relationship with the dependent variable is very similar to the logical acceptance of the independent variable relationship with the dependent variable. Furthermore, if the interaction between the moderator variable and the independent variable is significant, that means the effect of the independent variable in the dependent variable varies according to the level of the variable. In the multiple regression, it can be said that the simple beveling of the independent variable effect in the dependent variable varies according to the level of the moderator variable.

Then, when we need to distinguish between the moderator variable and the medium variable, the moderator variable is at the same level as the independent variable in determining their causal relationship with the dependent variable. Therefore, the moderator variables always act as independent variables, while the intermediate variable represents previous causal events arising from the independent variable Between independent and dependent variables.

Suddenly, before starting to set the variable of interaction, the data of the independent variable and the moderator variable must be converted to the centering or standardizing variables. Some prefer these variables are centered, that means the average data of each variable is extracted and subtracted from the average to obtain the formula of concentration for each variable "to address the problem of the high correlation between the independent variable and the individual variable with the interaction variable resulting from them. Thus, the concentration formula addresses the problem of the "Multicollinearity "between the variables" means, the high correlation between the variables explained in the regression equation. In point of view, Other statisticians can provide other benefits that can be obtained from the Standard measurement format, which facilitate the representation and interpretation of the effects of the interaction variable. To analyze the interactions between the variables, used the Social Science Statistics Program (IBM SPSS V.25).

\section{Steps in the analysis:}

1. First, conversion of the independent variable (Electronic Management) and moderator variable (Educational Competiotion ) data's which has (exploitation and exploration) dimension's to Standard measurement format (Z Scoring). 
2. Then, create an Interaction Variable, which is the result of the interaction of the moderator variable with the independent variable.

3. The third step is, Use the Hierarchical Regression Analysis technique to put the independent \& awkward variable in the first step then the interaction variable in the second other.

4. Fourth, Check the assumptions of the regression model used as well as the values of (R2) and change in value between the first step without the interaction variable and the second step with it so If the change is positive, this indicates the positive role that the interaction variable in the model has.

5. Check the significance of the second regression model (with an interaction variable) by testing (F).

6. addition, verifying the significance of the Unstandardized Coefficient coefficient of the interaction variable, if the coefficient is significant, this indicates the significance of the variable of the interaction, thus ensuring the interactive role of the modified variable in enhancing the effect of the independent variable in the awkward variable.

7. Calculating The Effect Size, which represents the ratio of the systematic variation attributed to the interaction variable relative to the unexplained variance in the adopted variable, that is the magnitude of the effect determines the level of effectiveness of the moderator variable in its interaction with the independent variable in the dependent variable, the magnitude of the effect is calculated according to the following equation: (Al Hasnawi,2015,233-236).

$$
f^{2}=\frac{R_{Y . A I}^{2}-R_{Y . A}^{2}}{1-R_{Y . A I}^{2}}
$$

Since:

- $\left(f^{2}\right)$ The Effect Size.

- $\left(R_{Y . A I}^{2}\right):$ The coefficient of interpretation resulting from the regression model with the interaction variable.

- $\left(R_{Y . A}^{2}\right)$ : The coefficient of interpretation resulting from the regression model without the interaction variable.

The results of the effect size can be explained by the Cahen rule as follows:

- if the value of $\left(0.02=f^{2}\right)$, The Effect Size is Low

- if the value is $\left(f^{2}=0.15\right)$, The Effect Size is Medium

- if the value of $\left(0.26=f^{2}\right)$, The Effect Size is High. 
8. Drawing an interactive with a plot shows the change in the moderator variable in the relationship between the independent variable and the dependent variable. The graph is an essential element of the analysis of the interactive relationship between the variables. It can be obtained by calculating the three levels of variable values modified by the mathematical equation $(1,0,-1)$ is the three moderator variable levels (Low, Medium, High). Thus, we will obtain three values for the modified variable for each level, Therefore, these values can be used to draw the interaction diagram by using Microsoft Excel.

\section{Third: The hypotheses of the interaction between the variables of the study Test}

In order to test the hypothesis of the main study, the acceptance of or rejection of the subhypotheses emanating from it was verified first and the level of the interactive role of the organizational skill and its dimensions as individual variables as modified variables in enhancing the effect of the independent variable (electronic management) in the dependent variable (intelligent organizations).

Primary subsidiary Hypothesis: There is an interactive role to exploit the current competencies in the promotion of electronic management and its impact on the activation of intelligent organizations.

Second subsidiary Hypothesis: There is an interactive role to explore new opportunities in the promotion of electronic management and its impact on the activation of intelligent organizations.

The main hypothesis: There is an interactive role to Educational Competiotion in the promotion of electronic management and its impact on the activation of intelligent organizations.

\section{1. primary subsidiary Hypothesis test}

The (Table 6) shows the parameters of Hierarchical regression analysis by testing the primary subsidiary Hypothesis of testing interactive role to exploit the current competencies in the promotion of electronic management and its impact on the activation of intelligent organizations. The first model represents the regression model that includes the effect of the independent and moderator variables, respectively electronic management and exploitation of the dependent variable "activating intelligent organizations". The second model represents the regression that 
includes the effect of the independent variable and the moderator variable as well as the Interaction variable (e-management * exploitation).

Table 6- The parameters of Hierarchical regression analysis by testing the primary subsidiary Hypothesis

\begin{tabular}{|c|c|c|c|c|c|c|}
\hline model & Variable & $\beta$ & T-test & significance & TOL & VIF \\
\hline \multirow[t]{3}{*}{1} & Constant & $6.445 \mathrm{E}-11$ & 0.000 & 1.000 & - & - \\
\hline & $\begin{array}{c}\text { Electronic } \\
\text { management }\end{array}$ & 0.250 & 2.745 & 0.007 & 0.873 & 1.145 \\
\hline & Exploitation & 0.094 & 1.033 & 0.303 & 0.873 & 1.145 \\
\hline \multirow[t]{4}{*}{2} & Constant & -0.096 & -1.157 & 0.249 & - & - \\
\hline & $\begin{array}{c}\text { Electronic } \\
\text { management }\end{array}$ & 0.422 & 4.443 & 0.000 & 0.710 & 1.409 \\
\hline & Exploitation & 0.122 & 1.426 & 0.157 & 0.868 & 1.152 \\
\hline & Interaction* & 0.272 & 4.183 & 0.000 & 0.768 & 1.302 \\
\hline
\end{tabular}

Source: Hierarchical regression analysis outcomes by using IBM SPSS 25 program.

(Table 7) shows the parameters of the regression model, where we note that the variable (exploitation) is insignificant at a significant level of $5 \%$, while the interaction variable is significant in both models. We also note that Tolerance values (TOL) are more than 0.1 and VIF values are less than 10 , which means that there is no problem with linearity (Multicollinearity)

Table 7- quality standards of Hierarchical regression model on primary subsidiary Hypothesis testing

\begin{tabular}{ccccccc}
\hline Model & $\mathbf{R}$ & $\begin{array}{c}\text { R2 } \\
\text { interpretation } \\
\text { factor }\end{array}$ & $\begin{array}{c}\mathbf{R}^{\mathbf{2}} \text { adj. } \\
\text { Adjusted } \\
\text { interpretation } \\
\text { factor }\end{array}$ & $\begin{array}{c}\text { R Square Change } \\
\text { Change in the } \\
\text { interpretation } \\
\text { factor }\end{array}$ & $\begin{array}{c}\text { F Change } \\
\text { Change in F } \\
\text { value }\end{array}$ & $\begin{array}{c}\text { Sig. F Change } \\
\text { significance of } \\
\text { the change in } \\
\text { the value of } \mathbf{F}\end{array}$ \\
\hline $\mathbf{1}$ & 0.297 & 0.088 & 0.074 & 0.088 & 6.082 & 0.003 \\
\hline $\mathbf{2}$ & 0.447 & 0.200 & 0.181 & 0.112 & 17.496 & 0.000 \\
\hline
\end{tabular}

source: Hierarchical regression analysis outcomes by using IBM SPSS 25 program.

The (Table 7) showed throw (R2), the explanatory capability of the first regression model is $8.8 \%$ and in the second regression, it is $20 \%$. This indicates a positive difference between the two models in the R2 value which reach $11.2 \%$. This difference is due to the entry of the interaction variable (E-management * exploitation) as a third variable in the second regression model, and by 
following the change in the significance of the regression model we find that it reaches (17.496), this change is significant at a significant level 0.05 .

By applying the magnitude of the impact equation $\left(f^{2}\right)$, it is clear that the level of impact of the Electronic Management in its interaction with Educational Competiotion in the development of intelligent organizations reach $(0.14)$, which is a small level of influence according to the classification of (Cohen). These results confirm the validity of the acceptance of pthe rimary subsidiary Hypothesis. This indicates the interactive role(moderator) of the current competencies in enhancing the effective relationship between electronic management and the development of intelligent organizations. (Figure 1) shows the graph of the interactive relationship between the study variables, which shows the three levels of exploitation of the current competencies (low, medium, high) and how they modify the relationship between electronic management and the development of intelligent organizations.

organizations, source: Microsoft Excel outcomes.

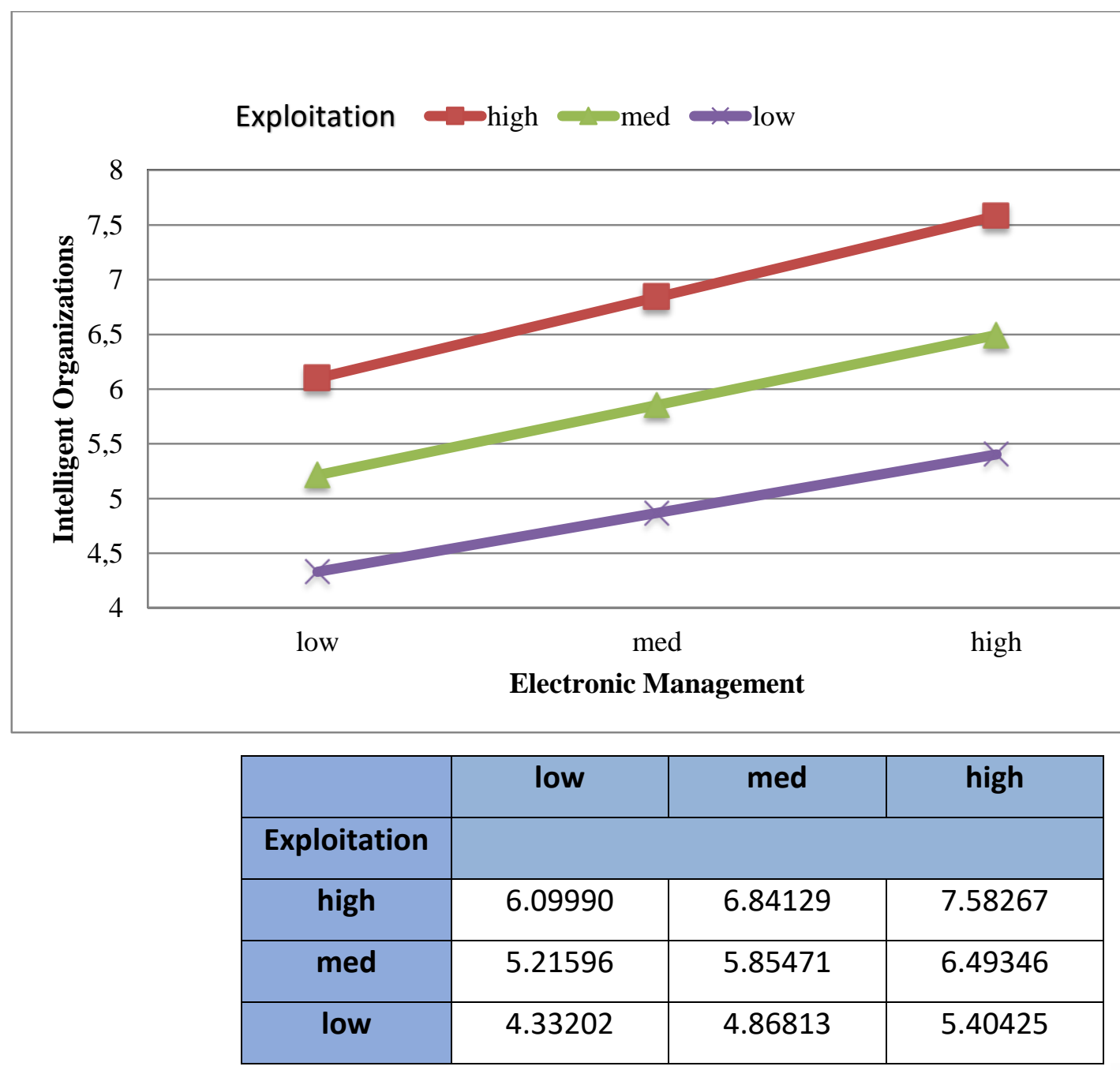


Figure 1- the interactive role to the exploitation of the current competencies in enhancing the influential relationship between electronic management and the development of intelligent

\section{2. second subsidiary Hypothesis test}

(Table 8) The parameters of Hierarchical regression analysis by testing the second subsidiary Hypothesis to exploration new opportunities in the promotion of electronic management and its impact on the activation of intelligent organizations. The first model represents the regression model that includes the effect of the independent and moderator variables, respectively electronic management and exploration of the dependent variable "activating intelligent organizations". The second model represents the regression that includes the effect of the independent variable and the moderator variable as well as the Interaction variable (Electronic Management * exploration).

Table 8- The parameters of Hierarchical regression analysis by testing the second subsidiary Hypothesis

\begin{tabular}{|c|c|c|c|c|c|c|}
\hline Model & Variable & $\beta$ & T-test & significance & TOL & VIF \\
\hline \multirow[t]{3}{*}{1} & constant & 5.439E-11 & 0.000 & 1.000 & & \\
\hline & Electronic management & 0.219 & 2.663 & 0.009 & 0.960 & 1.041 \\
\hline & Exploration & 0.321 & 3.897 & 0.000 & 0.960 & 1.041 \\
\hline \multirow[t]{4}{*}{2} & constant & -0.016 & -0.195 & 0.846 & & \\
\hline & Electronic management & 0.207 & 2.479 & 0.014 & 0.937 & 1.068 \\
\hline & Exploration & 0.308 & 3.695 & 0.000 & 0.936 & 1.068 \\
\hline & Interaction* & 0.081 & 0.959 & 0.339 & 0.940 & 1.064 \\
\hline
\end{tabular}

*Interaction Variable (Electronic Management * Exploration)

source: Hierarchical regression analysis outcomes by using IBM SPSS 25 program.

(Table 9) shows the parameters of the regression model, where we note that the Interaction Variable is insignificant at a significant level of $5 \%$, while the independent variable and Moderator is significant in both models. We also note that Tolerance values (TOL) are more than 0.1 and VIF values are less than 10, which means that there is no problem with linearity (Multicollinearity)

Table 9- quality standards of Hierarchical regression model on second subsidiary Hypothesis testing

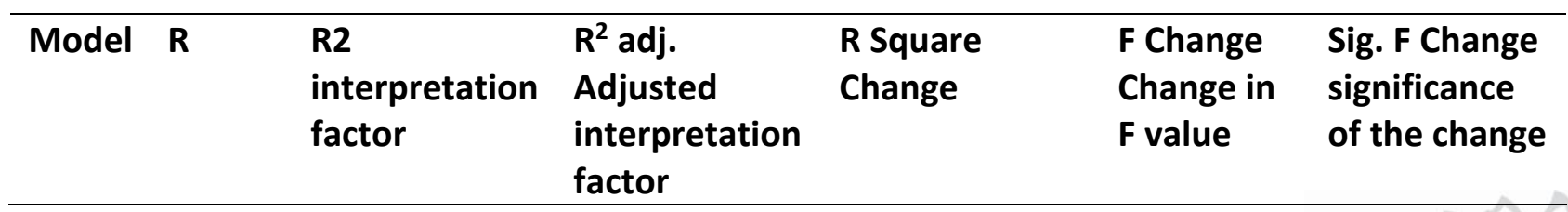




\begin{tabular}{|c|c|c|c|c|c|c|}
\hline & & & & $\begin{array}{l}\text { Change in the } \\
\text { interpretation } \\
\text { factor }\end{array}$ & & $\begin{array}{l}\text { in the value } \\
\text { of } F\end{array}$ \\
\hline 1 & 0.423 & 0.179 & 0.166 & 0.179 & 13.758 & 0.000 \\
\hline 2 & 0.430 & 0.185 & 0.166 & 0.006 & 0.921 & 0.339 \\
\hline
\end{tabular}

The (Table 9) showed throw (R2), the explanatory capability of the first regression model is $17.9 \%$ and in the second regression, it is $18.5 \%$. This indicates no difference between the two models in the $\mathrm{R} 2$ value which reach $0.6 \%$. Which means that the entry of the interaction variable (electronic management * exploration) as a third variable in the second regression model did not change much, and by following the change in the significance of the regression model we find that it was only (0.921) and this change is insignificant at a significant level 0.05 .

\section{DISCUSSION}

By applying the magnitude of the impact equation $\left(f^{2}\right)$, it is clear that the level of impact of the Electronic Management in its interaction with exploration in the development of intelligent organizations reach (0.007), which is no level of influence according to the classification of (Cohen). These results confirm not accepted of second subsidiary Hypothesis. This indicates no interactive role(moderator) of the to exploration new opportunities in enhancing the effective relationship between electronic management and the development of intelligent organizations. (Figure 2) shows the graph of the interactive relationship between the study variables showing the three levels of the exploration new opportunities (Low, Medium, High) and how it doesn't affect the relationship between e-management and intelligent organizations development 


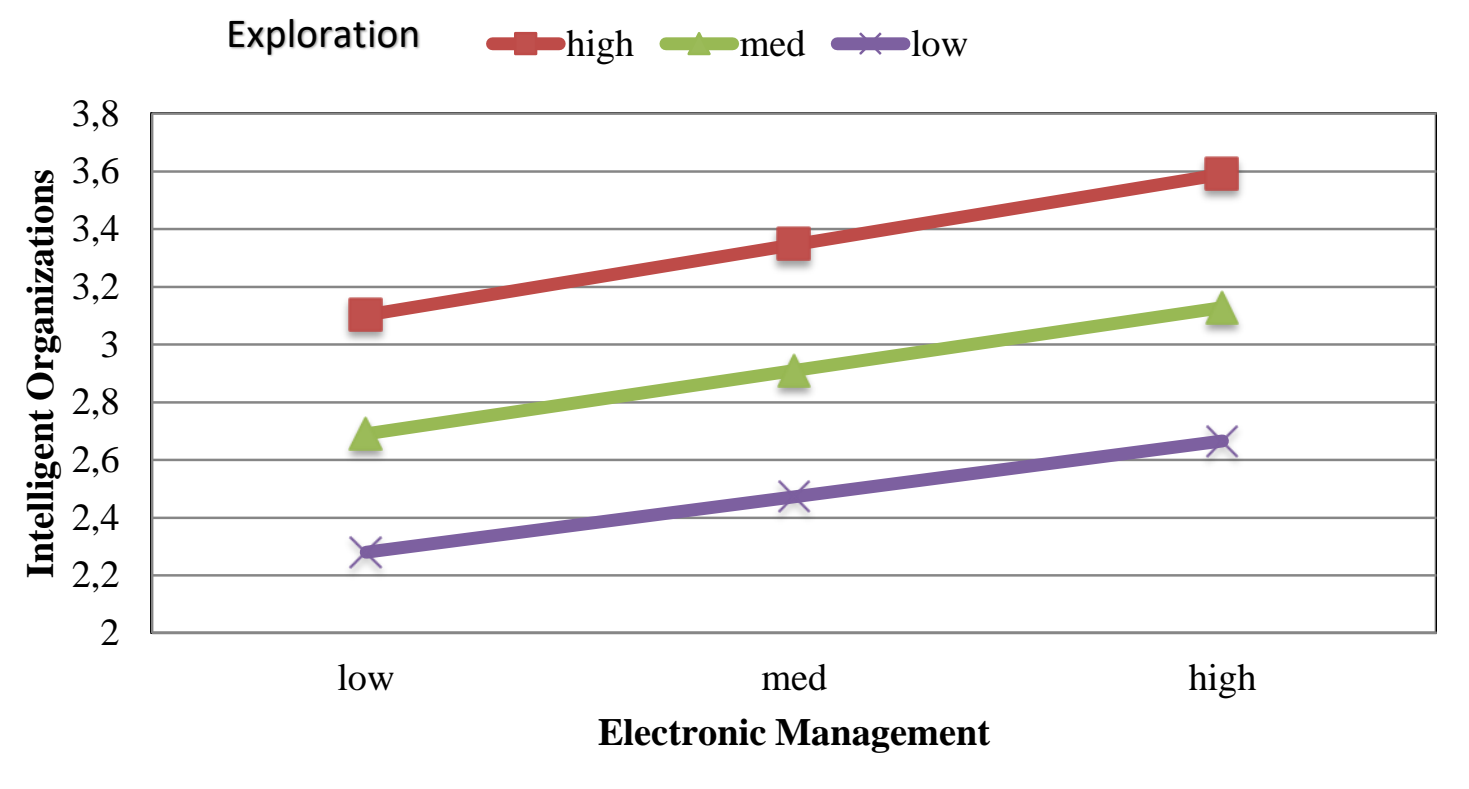

\begin{tabular}{|c|c|c|c|}
\hline & low & med & high \\
\hline Exploration & \multicolumn{3}{|l|}{} \\
\hline high & 3.10189 & 3.34606 & 3.59022 \\
\hline med & 2.69091 & 2.90938 & 3.12785 \\
\hline low & 2.27993 & 2.47270 & 2.66547 \\
\hline
\end{tabular}

Figure 2. the interactive role to exploration new opportunities in enhancing the influential relationship between electronic management and the development of intelligent organizations source: Microsoft Excel outcomes.

\section{The main hypothesis test}

(Table 10) The parameters of Hierarchical regression analysis by testing The Main Interactive Role Educational Competiotion in the promotion of electronic management and its impact on the activation of intelligent organizations. The first model represents the regression model that includes the effect of the independent and moderator variables, respectively electronic management and Educational Competiotion of the dependent variable "activating intelligent organizations". The second model represents the regression that includes the effect of the independent variable and the moderator variable as well as the Interaction variable (Electronic Management * Educational Competiotion). 
Table 10- The parameters of Hierarchical regression analysis by testing The main hypothesis

\begin{tabular}{ccccccc}
\hline Model & Variable & B & T-test & significant & TOL & VIF \\
\hline \multirow{2}{*}{2} & constant & $6.313 \mathrm{E}-11$ & 0.000 & 1.000 & - & - \\
\cline { 2 - 7 } & Electronic management & 0.176 & 2.027 & 0.045 & 0.878 & 1.138 \\
\cline { 2 - 7 } & Educational Competiotion & 0.307 & 3.535 & 0.001 & 0.878 & 1.138 \\
\cline { 2 - 7 } & constant & -0.064 & -0.771 & 0.442 & - & - \\
\cline { 2 - 7 } & Electronic management & 0.236 & 2.695 & 0.008 & 0.825 & 1.211 \\
\cline { 2 - 7 } & Educational Competiotion & 0.268 & 3.121 & 0.002 & 0.855 & 1.170 \\
\hline \multirow{4}{*}{ Interaction* } & 0.184 & 2.764 & 0.007 & 0.933 & 1.071 \\
\hline & *Interaction Variable (Electronic Management and Educational Competiotion ) \\
& source: Hierarchical regression analysis outcomes by using IBM SPSS 25 program.
\end{tabular}

(Table 11) shows the parameters of the regression model, where we note that all variables are significant at a significant level of $5 \%$, while the modified variable is significant in both models. Tolerance values are greater than 0.1 and VIF values are less than 10 . that means no (Multicollinearity).

Table 11- quality standards of Hierarchical regression model on The main hypothesis

\begin{tabular}{lllllll} 
Model & $\mathbf{R}$ & $\begin{array}{l}\mathbf{R 2} \\
\text { interpretation } \\
\text { factor }\end{array}$ & $\begin{array}{l}\mathbf{R}^{\mathbf{2}} \text { adj. } \\
\text { Adjusted } \\
\text { interpretation } \\
\text { factor }\end{array}$ & $\begin{array}{l}\text { R Square Change } \\
\text { Change in the } \\
\text { interpretation } \\
\text { factor }\end{array}$ & $\begin{array}{l}\mathbf{F} \text { Change } \\
\text { Change in } \mathbf{F} \\
\text { value }\end{array}$ & $\begin{array}{l}\text { Sig. F Change } \\
\text { significant of } \\
\text { the change in } \\
\text { the value of } \mathbf{F}\end{array}$ \\
\hline $\mathbf{1}$ & 0.404 & 0.163 & 0.150 & 0.163 & 12.296 & 0.000 \\
\hline $\mathbf{2}$ & 0.460 & 0.212 & 0.193 & 0.048 & 7.641 & 0.007 \\
\hline
\end{tabular}

source: Hierarchical regression analysis outcomes by using IBM SPSS 25 program.

It is clear from the (Table 11) (R2) that the explanatory capacity of the first regression model was $16.3 \%$ and the second regression was $21.2 \%$. This indicates that there were differences between the two models in the value of (R2) which reached $4.8 \%$ (Electronic management * Educational Competiotion) as a third variable in the second regression model, and by following the change in the significance of the regression model we find that it reached (7.641) and this change is significant at a significant level 0.05 .

By applying the magnitude The Effect Size $\left(f^{2}\right)$, it is clear that the level of influence that the Electronic Management has introduced in its interaction with Educational Competiotion in the development of intelligent organizations has reached (0.06), which is a small influence level according to the classification of (Cohen). These results confirm the validity of the acceptance of the 
main hypothesis, and this indicates the interactive role (modified) of Educational Competiotion in enhancing the influential relationship between electronic management and its impact on the development of intelligent organizations. The graph shows the interactive relationship between study variables that shows the three levels of Educational Competiotion (low, medium, high) and how they modify the relationship between electronic management and the development of intelligent organizations (Figure 3).

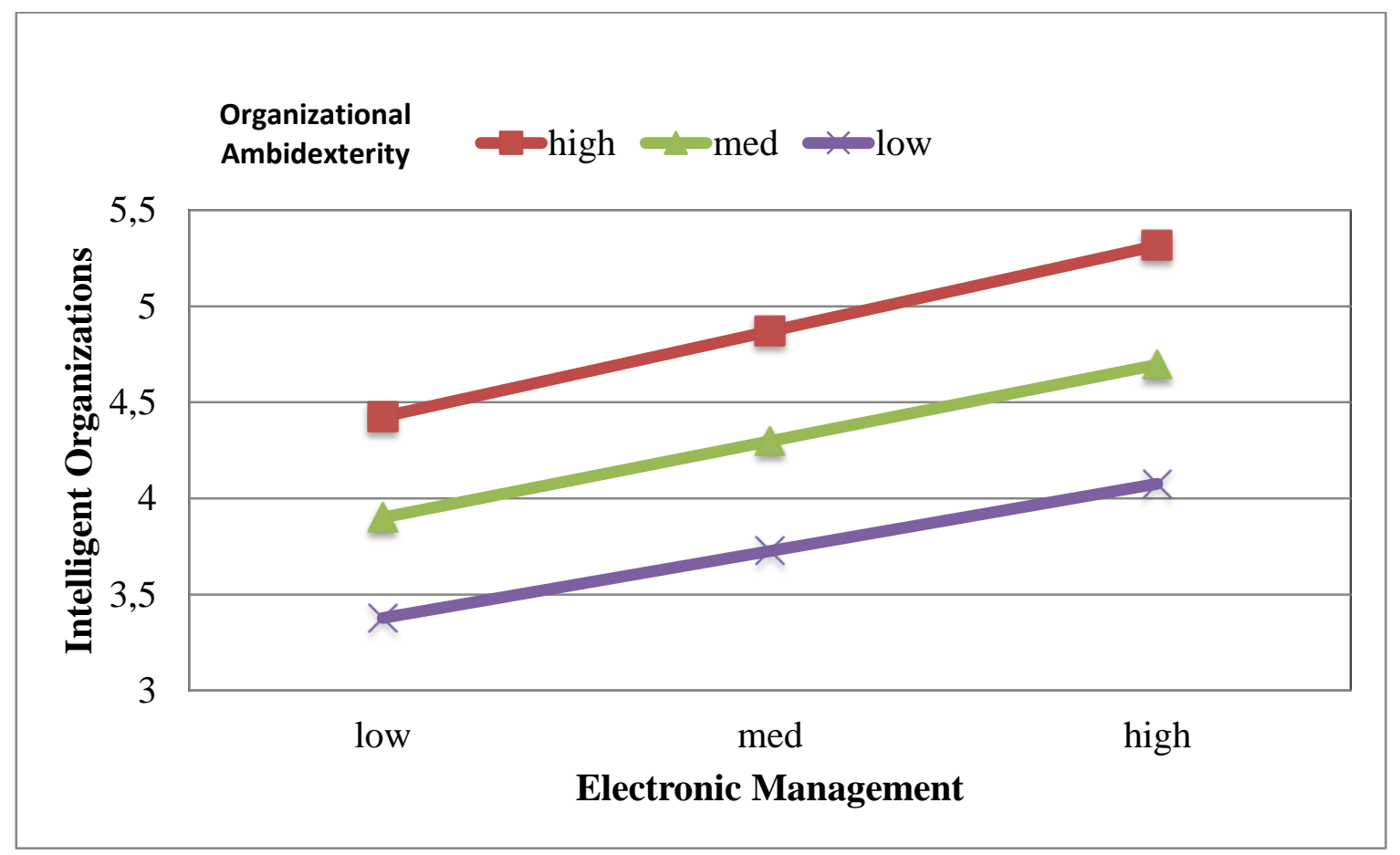

\begin{tabular}{|c|c|c|c|}
\hline & low & med & high \\
\hline $\begin{array}{c}\text { Educational } \\
\text { Competiotion }\end{array}$ & \multicolumn{2}{|l}{} \\
\hline high & 4.42387 & 4.86997 & 5.31607 \\
\hline med & 3.90018 & 4.29792 & 4.69567 \\
\hline low & 3.37648 & 3.72588 & 4.07527 \\
\hline
\end{tabular}

Figure 3- The interactive role of Educational Competiotion in enhancing the influential relationship between electronic management and the development of intelligent organizations source: Microsoft Excel outcomes.

Based on the above, the results of hypotheses as a whole support the interactive role of the moderator variable in the independent variable and its effect on the dependent variable. As for the 
sub-hypotheses, the reason for the lack of morale is due to the lack of the number of questions in the measurement of the Educational Competiotion of the second exploitation and exploration, where the number of questions for each dimension is five questions, thus the total of ten questions to measure Educational Competiotion. The implications of this should be more detailed questions in terms of Educational Competiotion in order for the results to be significant and the measurement is more reliable and accurate and this is preferred to be addressed in other future studies. Given the importance of the subject of Educational Competiotion, which should be taken in an independent study to determine the best measure.

\section{CONCLUSION}

Electronic Management is a good example of the administration and works to distinguish the organization in the era of informatics. And the beginning of the transition to intelligent organizations. When implementing the application, the company has the financial, technical and human resources necessary to implement the electronic management. But the company needs more HR training and training programs and there is a system of incentives to promote the shift towards electronic management. Moreover, it needs a large database to connect with all branches in Iraq, because electronic management is a competitive advantage for market superiority. addition, Laws, and regulations must also be organized by the organizations to regulate electronic management and the state legislates the relevant laws. The organization also needs a strategic framework that regulates and directs the requirements of electronic management to achieve successful implementation. There must be a design of the organizational structure of the company in line with the electronic management programs. wherever, the use of electronic management works on the speed of completion of work and with great accuracy while saving time and effort and increasing the efficiency of the employees, which leads to raising the productivity of the company. The analysis of the views of the sample leads to the failure to prove the primary and second subhypothesis of the research because of the effect of a small and non-significant and this is the result of several reasons. Including the small number of questions used in each dimension of Educational Competiotion (exploitation, exploration). This requires future studies to develop a more detailed questionnaire. The company's staff and department managers also need awareness-raising sessions on the importance of Educational Competiotion and its role in achieving competitive excellence and moving towards intelligent organizations. As well as the need for administrative leaders to take care 
of both exploitation and exploration activities and to take into account the achievement of compatibility and consistency between these two types of contradictory activities. As well as activate the contribution of employees in the development of the company's strategy by involving the members of the team in the planning process at the departmental level. The theme of intelligent organizations is one of the most important issues faced by contemporary organizations: continuous change in markets, increasing global competition and sudden changes in the technological environment. The company should also promote trust, transparency, and information to contribute to the building of intelligent organizations. And to work on the development of the core capabilities of human resources, which contribute to building the model of intelligent organizations. Finally, the main hypothesis is done.

\section{REFERENCES}

Aboudi, Safa Idris, and Kharofa, Raghad Mohammed. (2018). Organizational Tactics an Approach to Strategic Fitness / Field Study in a Sample of Mobile Telecommunications Companies in Iraq. Journal of Economic and Administrative Sciences, vol. 24, No. 109. 240-258.

Aboudi, Safa Idris, Yahya, Raghad Mohammed. (2018). E-Management Introduction to Social Interaction / Analytical Study in the Faculty of Medicine. Ninewa, Tikrit Journal of Administrative and Economic Sciences, Volume (2), Issue (42). 120-132.

Abu-Olba, Tamer Mohamed Ahmed. (2018). The role of talent management in building the intelligent organization in the Palestinian industrial establishments. Master Thesis, Faculty of Commerce, Islamic University of Gaza. 1-194.

Al hasnawi. (2015). The Interactional Role for Organizational Integrity in Enhance of Impact Authentic Leadership Behaviors in Strategic Human Resources Development. PhD thesis, collage of Administration and Economics University of Karbala. Iraq.

Al-Aqabi, Nasser Awaid Attieh, and Al-Rubaie, Kholoud Hadi Abboud. (2018). Analysis of the Requirements of E-Management and its Role in Improving Human Resources Functionality, vol. 13, No. 45. 63-95.

Al-Asadi, Afnan Abd Ali. (2009). Electronic management between theory and application requirements in the environment of Iraqi business organizations. Journal of the Center for the Study of Kufa, Volume (1), Issue (15). 111-132.

Al-Badran, Aroba Rashid Ali, Mohsen, Abdul Rida Nasser. (2014). The reality of electronic administration in service organizations and their applicability / case study in the Directorate of Basra Municipality. Journal of Economic Sciences. Vol. 10, No. 37. 111-148.

Al-Baghdadi, Adel Hadi, and Jubouri, Haidar Jassim Obaid. (2015). The impact of Educational Competiotion in achieving strategic flexibility. Qadisiyah Journal of Administrative and Economic Sciences, Vol. (17), Issue (1). 17-32. 
Al-Bannaa, Zeinab Makki Mahmoud. (2016). The role of Educational Competiotion in building learning organizations through radical innovation. Journal of Karbala Scientific University, Volume (14), Issue (2). 228-256.

Al-Daini, Rasha Khudair Wahid. (2010). The impact of electronic management and the role of human resource development in improving the performance of the organization. Master of Business Administration, Faculty of Business Administration, Middle East University, Jordan. 1-139.

Al-Jumaili, Ahmed Mohammed Jassim. (2018). The possibility of implementing the electronic management in the management of the insurance industry \Exploratory study in the National Insurance Company. Journal of the College of Science City University, Volume (10), Issue (2). 235251.

Al-Karaawi, Saja Jawad Hussein. (2016). The Influence of Intelligent Leadership in Intelligent Organizations by Enhancing Organizational Learning, Master Thesis, Faculty of Management and Economics, Qadisiyah University, Iraq. 1-122.

Al-Mahasna, Lamis Aref Abed-Rabbo. (2017). Intermediate role of Educational Competiotion in the relationship between dynamic capacity and organizational agility. Master of Business Administration, Business School, Middle East University, Jordan. 1-158.

Al-Taei, Yousef Hajim, Al-Sayegh, Muhammad Jabbar, Hadi, Qaysar Ali. (2013). Formulating the Company's Sustainable Strategy in Building Intelligent Organizations, Al-Ghari Journal of Economic and Administrative Sciences, Volume 9, No. 26. 119-150.

Cherniss, C., \& Goleman, D. (2001). The emotionally intelligence workplace. How to select for measure and improve emotional intelligence in individuals, groups and organizations san Francisco: Jossey-Bass.

Chou, C., Yang, K. P., \& Chiu, Y. J. (2018). Managing sequential ambidexterity in the electronics industry: roles of temporal switching capability and contingent factors. Industry and Innovation, 25(8), 752-777.

Dahwan, Abdullah bin Saeed Al-Waleed. (2008). The Role of the Department of Administrative Development in the Application of Electronic Management. Master of Public Administration. College of Business Administration. King Saud University. 1-123.

Dhahes, Zafer Mayouf, Mohsen, Amal Ali, and more, Rashid Hamid. (2013). The availability of the basic components of the shift towards electronic administration in Iraqi universities $\backslash$ Applied study in higher education institutions in Al-Nasiriyah. Journal of Technical, Volume (26), Issue (7). 289311.

Firaun, Mohammed Thabet, Al-Anzi, Saad Ali, and Khaldi, Awad Kazem. (2015). Develop a business strategy to develop intelligent organizations model. Al Ghari Journal of Economic and Administrative Affairs, vol. 10, no. 33, 113-137.

Firaun, Mohammed Thabit, Al-Anzi, Saad Ali, and Al-Khalidi, Awad Kazem. (2015). Building human resource capacity and its role in developing intelligent organizations model. Al-Ghari Journal of Economic and Administrative Sciences, vol. 13, No. 36. 139-161. 
Ghuneim, Ramzi Muhammad Ismail. (2017). The impact of the use of MIS in promoting intelligent organization building. Master degree, Department of Business Administration, Faculty of Commerce, Islamic University of Gaza. 1-163.

Gibson, C. B., \& Birkinshaw, J. (2004). The antecedents, consequences, and mediating role of Educational Competiotion . Academy of management Journal, 47(2), 209-226.

Hassan, Fadel Abbas. (2013). The role of organizational culture in the contemporary orientation towards applications of electronic management \field study at the University of Maysan, No. (9). 221-255.

Hassan, Samia Mahdi, Hatem, Waddah Amer, Khalaf, Jasim, Hashem, Kawther. (2016). Study of the obstacles of the application of electronic management in Iraqi educational institutions. Diyala Journal of Engineering Sciences, Volume (9), Issue (3). 12-24.

Hussain, Huda Abdulrahim, and Alani, Alaa Abdumawgood. (2018). Compatibility between large data entry and organizational proficiency / exploratory survey of the views of a sample of managers at Asia Cell Mobile Telecommunications Company in Iraq. Journal of Economic and Administrative Sciences, vol. 24, No. 105. 216-293.

Ibrahim, Maha Mosabah. (2017). Educational Competiotion and its Effect on Achieving Strategic Success / Applied Study in the Iraqi National Bank, Journal of Accounting and Financial Studies, Vol. (12), Issue (39). 204-230.

Jaafar, Qubas Zuhair Abdulkarim. (2014). The Effect of Electronic Management in Total Quality Management \Case Study in the Department of Information Technology, Ministry of Science and Technology. Baghdad. Journal of Administration and Economics, Vol. 37, No. (100), 123-144.

Judy, Haidar Hamza, Abdulrahman, Youssef Fouad (2011). The Effect of Management on Roaming in Developing the Work of Electronic Management, Journal of Administration and Economics, Volume (34), Issue (90). 321-338.

Lubatkin, M. H., Simsek, Z., Ling, Y., \& Veiga, J. F. (2006). Ambidexterity and performance in smallto medium-sized firms: The pivotal role of top management team behavioral integration. Journal of management, 32(5), 646-672.

Popadić, M., Černe, M., \& Milohnić, I. (2015). Educational Competiotion , exploration, exploitation and firms innovation performance. Organizacija, 48(2), 112-119.

Radaida, Inas Mohammed Amin Ahmed. (2016). The impact of the organization's intelligent properties in crisis management. Master degree, Business School, Middle East University. Oman. 1128.

Radi, Jawad Mohsen, Hussein, Saja Jawad. (2017). The role of distance learning organizational in the transformation to intelligent organizations. Qadisiyah Journal of Administrative and Economic Sciences, vol. 19, no. 3, 6-33.

Radi, Jawad Mohsen, Qassem, Zahraa Naeem. (2018). Strategic direction in the achievement of Educational Competiotion / survey study of the views of a sample of managers of some private banks. Journal of Administration and Economics, vol. (7). Number (25). 105-139. 
Raisch, S., \& Birkinshaw, J. (2008). Educational Competiotion : Antecedents, outcomes, and moderators. Journal of management, 34(3), 375-409.

Saber, Rana Nasser, Amiri, Sarah Ali Saeed, Abdulhussein, Ali Abdulamir. (2018). The interactive role of competitive intelligence to enhance the impact of Educational Competiotion in achieving customer delight $\backslash$ field research on a sample of travel and tourism companies in Baghdad. Journal of Administration and Economics, vol. (41). Number (117). 107-125.

Schwaninger, M. (2001). Intelligent organizations: an integrative framework. Systems Research and Behavioral Science: The Official Journal of the International Federation for Systems Research, 18(2), 137-158.

Shehab, Shahrazad Mohammed. (2013). The extent to which electronic management can be implemented in secondary and middle schools from the point of view of school principals in the center of Nineveh province. Journal of Education and Science. Volume (20), Issue (2). 321-360.

Suweis, Mohammed Ibrahim Kamel, Abdeen, Ibrahim Abd Seleem. (2019). The role of business intelligence systems in building organizational skill by applying to banks operating in Palestine. Journal of the Islamic University for Economic and Administrative Studies, Volume 27, Issue 1. 167201.

Taródy, D. (2016). Educational Competiotion as a new research paradigm in strategic management. Vezetéstudomány-Budapest Management Review, 47(5), 39-52.

Tuan, L. T. (2016). Organisational ambidexterity and supply chain agility: The mediating role of external knowledge sharing and moderating role of competitive intelligence. International Journal of Logistics Research and Applications, 19(6), 583-603.

Zidane, Ihsan Adnan, Abdulghani, Wissam Imad, Mohammed, Mohammed Adnan. (2018). Obstacles to the application of electronic administration at the University of Diyala. Al-Fath Magazine, Issue (74). 307-339.

\section{Appendix Questionnaire:}

\begin{tabular}{llll}
\hline Electronic management & $\begin{array}{l}\text { Totally } \\
\text { agree }\end{array}$ & $\begin{array}{c}\text { Agree } \\
\text { Neutral }\end{array}$ & $\begin{array}{c}\text { Don't } \\
\text { agree }\end{array}$ \\
\hline $\mathbf{1}$ & $\begin{array}{l}\text { Totally } \\
\text { don't } \\
\text { agree }\end{array}$ \\
\hline & $\begin{array}{l}\text { The organization relies on electronic methods in } \\
\text { completing all administrative transactions between } \\
\text { departments }\end{array}$ & \\
\hline $\mathbf{2}$ & $\begin{array}{l}\text { The organization uses modern software to control } \\
\text { inter-departmental administrative activities }\end{array}$ & \\
\hline $\mathbf{3} \quad \begin{array}{l}\text { The Organization updates the programs for the } \\
\text { completion of administrative transactions on an } \\
\text { ongoing basis to be more accurate }\end{array}$ & \\
\hline $\mathbf{4} \quad \begin{array}{l}\text { The organization uses artificial intelligence programs } \\
\text { to accomplish some administrative tasks }\end{array}$ & \\
\hline
\end{tabular}


$5 \quad$ Electronic management has contributed to reducing the time of completion of tasks

6 Electronic management has contributed to reducing bureaucracy

7 Electronic management has provided more time for employees to perform more important responsibilities

8 Modern techniques are used in reverse feeding to reduce problems during work

\section{Technical requirements}

9 The organization uses an internal intranet linking all the departments together

10 The organization contracts with international companies in the development of modern nonpenetrable software to protect the data and is constantly updated by the equipped company.

11 Electronic devices and equipment are updated continuously

12 The organization uses cloud computing to provide integrated computing services without being restricted to local resources

13 Provide guidelines for electronic management application mechanisms

14 The organization has a main server that connects all computers and coordinates operations

\section{Human requirements}

15 High confidence in all electronic transactions

16 There are an appropriate number of personnel specialized in the operation and maintenance of hardware and software

17 English skills for high-caliber employees

18 Provides the conviction of change workers from traditional organizations to smart organizations

19 High awareness of the importance and protection of information security

20 The organization has human resources with high experience in the field of information and communications systems

21 E-management has contributed to the addition of skills and expertise to human resources in the use of software

\section{Educational Competiotion}

Totally Agree Neutral agree

Don't Totally

\section{Exploitation}

22 The organization is trying to use resources very much

23 The organization is interested in meeting the needs of existing customers 
24 The organization has sufficient capacity to improve its activities at present

25 The organization seeks to expand its skills and knowledge

26 The organization is interested in increasing economies of scale in its current markets

\section{Exploration}

27 FAO has the ability to predict events when starting a new project

28 FAO has the ability to exploit market opportunities explored

29 FAO has the capacity to adapt to environmental fluctuations

30 Our organization accepts demands that go beyond its current services

31 The organization seeks to create new products and services

\begin{tabular}{|c|c|c|c|c|c|}
\hline & Intelligent organizations & $\begin{array}{l}\text { Totally Agree } \\
\text { agree }\end{array}$ & Neutral & $\begin{array}{l}\text { Don't } \\
\text { agree }\end{array}$ & $\begin{array}{l}\text { Totally } \\
\text { don't } \\
\text { agree }\end{array}$ \\
\hline & \multicolumn{5}{|l|}{ Understanding the environment } \\
\hline 32 & $\begin{array}{l}\text { Environmental uncertainties are accurately } \\
\text { diagnosed }\end{array}$ & & & & \\
\hline 33 & $\begin{array}{l}\text { Environmental uncertainties are taken into } \\
\text { account when making any decision }\end{array}$ & & & & \\
\hline 34 & $\begin{array}{l}\text { Systems and specialists are available to assess } \\
\text { the effects of environmental uncertainties }\end{array}$ & & & & \\
\hline 35 & $\begin{array}{l}\text { Sources of environmental uncertainty are } \\
\text { identified for decision-making }\end{array}$ & & & & \\
\hline \multirow[t]{2}{*}{36} & $\begin{array}{l}\text { Environmental uncertainties related to } \\
\text { decisions are identified and communication is } \\
\text { made with specialists to address them }\end{array}$ & & & & \\
\hline & Strategic vision & & & & \\
\hline 37 & $\begin{array}{l}\text { A systematic review of the work environment } \\
\text { is undertaken to identify opportunities and } \\
\text { threats }\end{array}$ & & & & \\
\hline 38 & $\begin{array}{l}\text { There is an ongoing discussion of the working } \\
\text { environment and methods used to meet } \\
\text { current and future challenges }\end{array}$ & & & & \\
\hline 39 & $\begin{array}{l}\text { Senior management is transparent about } \\
\text { strategic directions }\end{array}$ & & & & \\
\hline 40 & There is a clear guide to guide the work & & & & \\
\hline \multirow[t]{2}{*}{41} & $\begin{array}{l}\text { There is a clear vision for the organization and } \\
\text { is recognized by all employees }\end{array}$ & & & & \\
\hline & Continuous learning & & & & \\
\hline
\end{tabular}


42 Senior management welcomes new creative ideas

43 There are practical measures aimed at continuous learning to cope with environmental changes

44 Opportunities are identified based on their distinctiveness

45 Opportunities and resources are provided for learning

46 Positive change is seen as an important and profitable process

\section{Smart Operations}

47 Modern and advanced technologies are employed

48 The information systems used to support the wide and free flow of information

49 The systems used to enable employees to perform their tasks efficiently and effectively

50 The systems used to provide early crisis warning for strategic decision making in a timely manner

51 There is a rapid adaptation to accelerating environmental changes

\section{Collective intelligence}

52 In the organization, there is collective action and team spirit

53 There is a strategic team capable of dealing with changing circumstances

54 The strategic work team consists of distinguished individuals and different disciplines

55 There is an organizational climate that promotes collective creativity

56 Teamwork teams have special social ties

\section{ABOUT THE AUTHOR}

\section{Ali Abdulhassan Abbas}

Professor at the Department of Accounting, College of Administration and Economics, University of Kerbala. Karbala, Iraq. E-mail: Fuhrer313@gmail.com, ali.abd.alhassan@uokerbala.edu.iq ORCID: https://orcid.org/0000-0001-6860-2583 